食道癌頸部リンパ節郭清後に発生した頸部胸管瘦の 2 例

\begin{tabular}{llllll}
\multicolumn{6}{c}{ 久留米大学医学部第 1 外科 } \\
藤井 & 輝彦 & 藤田 & 博正 & 山名 & 秀明 \\
白水 & 玄山 & 南 & 泰三 & 掛川 & 暉夫
\end{tabular}

\title{
CERVICAL THORACIC DUCT FISTULA FOLLOWING RADICAL OPERATION FOR CARCINOMA OF THE THORACIC ESOPHAGUS -REPORT OF TWO CASES-
}

\author{
Teruhiko FUJII, Hiromasa FUJITA, Hideaki YAMANA, \\ Genzan SHIROUZU, Taizo MINAMI and Teruo KAKEGAWA
}

First Department of Surgery, Kurume University School of Medicine

索引用語：食道癌頸部リンパ節郭清術，食道癌術後合併症，頸部胸管瘦

はじめに

胸部食道癌におけるリンパ節転移は頸胸腹と広範に わたることから, 従来の胸部, 腹部リンパ節郭清に加 え, 頸部リンパ節郭清も重要視されるようになった1). しかし，頸部，上綐隔リンパ節の徹底した郭清を行う と, 肺合併症や反回神経損傷などの合併症も少なくな い2).さらに, 特殊な合併症として胸管損傷もその $1 つ$ に数觉られる。胸管損傷の主なものは，胸腔内に乳糜 が貯留する乳糜胸であり，それについては多くの報告

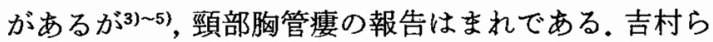
は, 頸胸境界部の腫瘍（消化管囊腫）摘出後に頸部胸 管瘦を発生した 8 歳女坚の症例を報告しているが6), 食道癌頸部リンパ節郭清後に発症をみたという報告は まだない，私達は食道癌頸部りンパ節郭清術後に発生 した頸部胸管瘦を 2 例経験したので, 症例を供覧し, 文献的考察を加光報告する.

$$
\text { 症例 }
$$

症例 $1: 61$ 歳, 男性.

$\operatorname{Iu}>\operatorname{Im}\left(\right.$ 食道癌取扱い規䄪 ${ }^{4}$ 亿準拠，以下規約と略 す)に長径 $5 \mathrm{~cm}$, ラセン型の食道癌を認め, 30Gy の術 前照射の後，右開胸開腹食道亜全摘，胸骨後食道胃吻 合術, 胃瘦造設, 左頸部リンパ節郭清術を施行した。 郭清した頸部リンパ節は左鎖骨上リンパ節（No. 104), 左深頸リンパ節 (No. 102), 頸部傍食道リンパ 節（No. 101）であった（リンパ節番号は規約に準拠,

$<1989$ 年 6 月 7 日受理 $>$ 別刷請求先：藤井 輝彦

$\overline{\mathrm{T}} 830$ 久留米市旭町 67 久留米大学医学部第 1 外科
以下同様). 規約による組織学的進行度は $a_{3}$ (気管) $n_{0}$ $\mathrm{M}_{0} \mathrm{Pl}_{0}$ stage IV であった. 術後 3 日目より頸部創から 多量の漏出液を認めたため, 頸部創を正迫し経過観察 していたが，漏出液は減少しなかった，胸管損傷によ るリンパ漏と判断し, 絶食とし, intravenous hyperalimentation(IVH), 経腸栄養による栄養管理を行っ た。その後, 排灘量は増減を繰り返し，1 日平均漏出 量は $347 \mathrm{ml}$ であった，図 1 は漏出液量の推移と栄養管 理の方法を示している.全身状態は徐々に不良となり， 低 $\mathrm{Na}$ 血症, 低 $\mathrm{Cl}$ 血症, 代謝性アルカローシスを認め た。術後的 4 か月後, 頸部創の感染之释合不全から敗 血症を来し disseminated intravascular coagulation (DIC) となった。ささらに, 腎不全, 心不全, 呼吸不全 と multiple organ failure (MOF) を来し, 術後約 5

図 1 症例 1 の栄養管理と漏出液量の推移：栄養管理 はIVH, 経腸栄養と経口摂取で行った. IVH のみの 時は, 漏出液量は減少している。1 日平均漏出液量 は347ml であった。

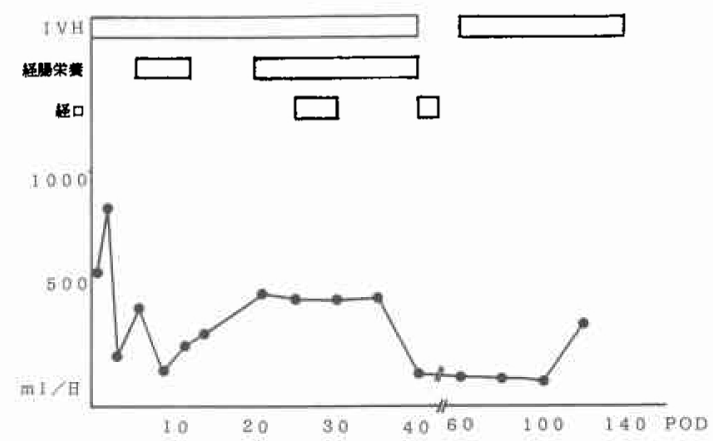


図 2 症例 1 の術後経過：全身状態は徐々に不良とな $\eta$, 著明な低 $\mathrm{Na}$ 血症, 低 $\mathrm{Cl}$ 血症さらに代謝性アル カローシスを認めた。

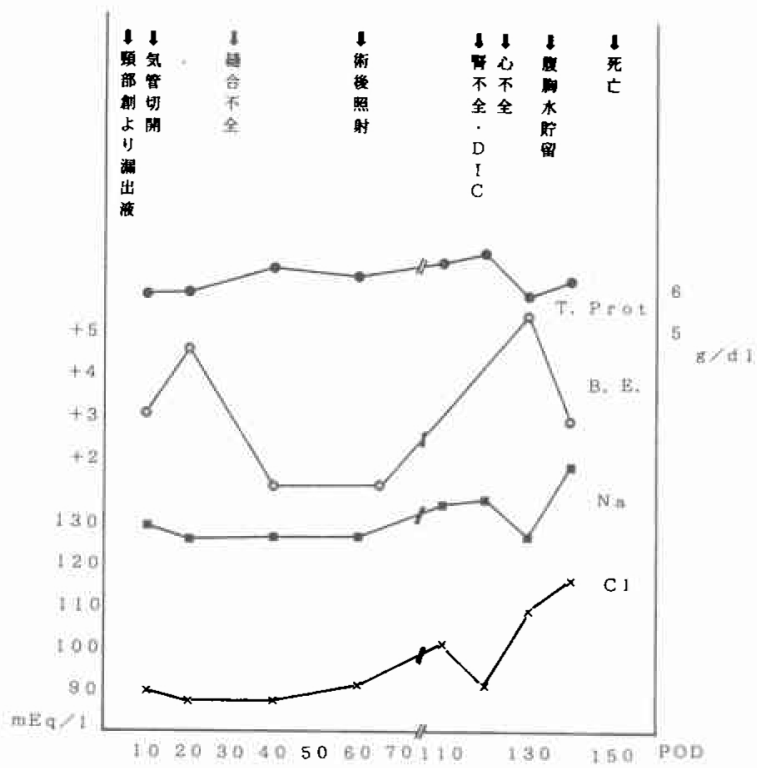

図 3 症例 2 の栄養管理と屚出夜量の推移: 栄盖管理 はIVH，経腸栄養と経口摂取で行った，胸管瘻閉鎖 術後には, 漏出液は著明に減少した。1 日漏出液量 は523mlであった。

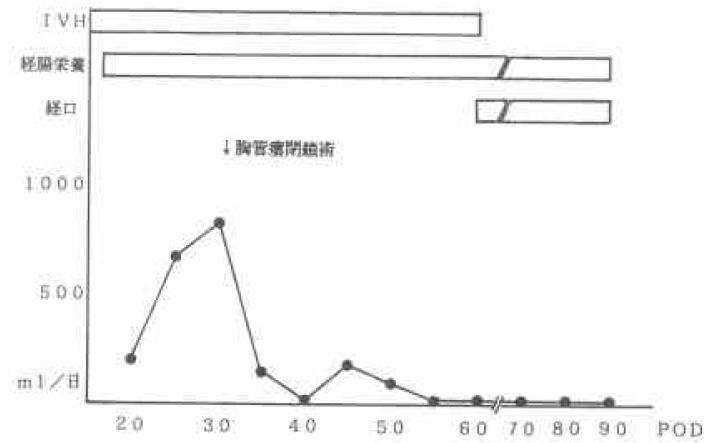

か月で死亡した，図 2 は術後の臨床経過と血将蛋白， Base Excess，電解質 $(\mathrm{Na}, \mathrm{Cl})$ の推移を示したもの である。

症例 $2: 57$ 歳, 男性.

$\operatorname{Im}$ に長径 $7 \mathrm{~cm}$, 鋸歯型の食道癌を認め, 右開胸開腹 食道亜全摘, 胸壁前食道胃吻合術, 胃瘦造設, 両側頸 部リンパ節郭清術を行った. 郭清した頸部リンパ節は, 両側とも鎖骨上リンパ節 (No. 104), 深頸リンパ節 （No. 102，頸部傍食道リンパ節（No. 101）であった。
図 4 症例 2 の術後経過：胸管瘦閉鎖術後に血浆蛋白 は著明に上昇, 代謝性アルカローシスは改善し, 低 $\mathrm{Na}$ 血症, 低 $\mathrm{Cl}$ 血应も徐々に改善した。

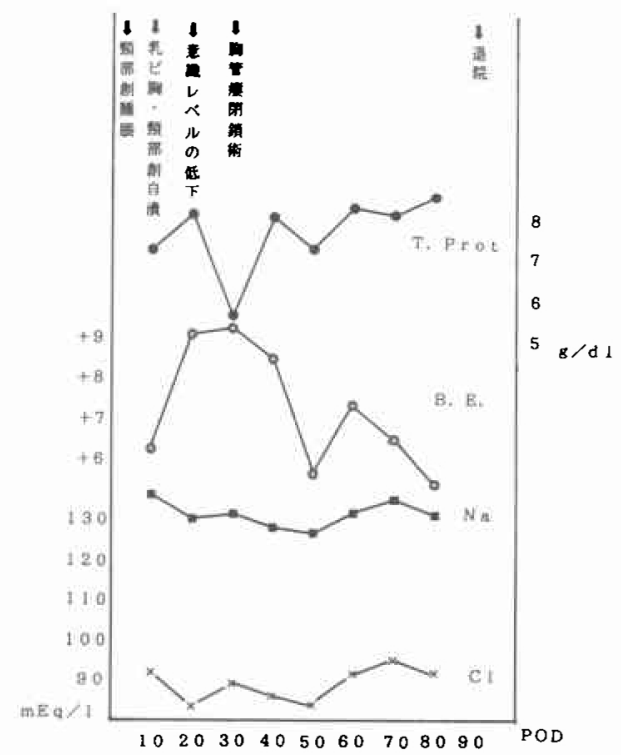

術中，左鎖骨上リンパ節を郭清している際，胸管を損 傷したのでこれを結禁した。しかし，術後 1 週目より 左頸部皮下に貯留液を認め, 術後14日目には乳糜胸と なった。同時期より頸部創が自潰し，漏出液の流出を 認め, その量は 1 日平均 $523 \mathrm{ml}$ であった. 頸部創を開放 し，持続吸引としたところ，胸腔ドレーンからの乳糜 の流出は止まったが, 頸部創より吸引される漏出液は 減少しなかった。頸部胸管瘻と診断し, IVH, 経腸栄 養による栄養管理を行った（図３）。しかし，低 $\mathrm{Na}$ 血 症, 低 $\mathrm{Cl}$ 血症となり, $\mathrm{Co}_{2}$ ナルコーシスを繰り返すよ うになったため, 術後21日目に頸部胸管瘦閉鎖術を 行った。手術は局所麻酔下に施行した。乳糜の漏出部 位を確認するために，術直前に経腸栄養チューブより 牛乳を注入していたため, 乳糜の漏出部位は容易に確 認された。しかし，胸管そのものは発見できなかった ので,リンパ漏出部を肉芽とともに4-0ナイロン系にて マットレス縫合で結紮し, その上から接着剤で補強し, ガーゼで王迫した。術後 5 日目よりリンパ液の漏出は 止まり, 全身状態は改善し, 術後約 3 か月で退院となっ た（図４).

\section{考察}

乳糜胸と頸部胸管瘻において, 両者の乳糜を趣失す ることに関する病態生理は全く同一で, 電解質異常, 蛋白, 特にアルブミン, 脂肪, 脂溶性ビタミンなとの 
図 5 頸部胸管瘻の病態生理

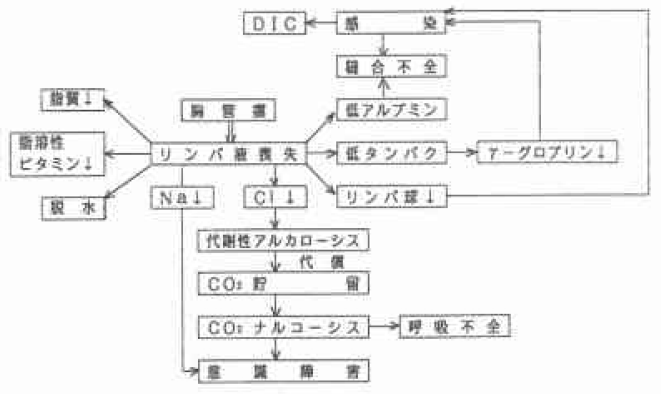

喪失などがその主なものである6/8). 乳糜中には $\mathrm{Naが}$ $104 \sim 108 \mathrm{mEq} / l, \mathrm{Cl}$ が85 $103 \mathrm{mEq} / l$ 含まれ ${ }^{9)}$, 乳糜喪 失に伴う低 $\mathrm{Na}$ 血症, また, $\mathrm{Cl}$ イオンは $\mathrm{HCl}$ の形で失 われるため, 代謝性フルカローシスを伴ら低 $\mathrm{Cl}$ 血症と なる.この代謝性アルカローシスを代償しょうと, 呼 吸が抑制され， $\mathrm{CO}_{2}$ が貯留し， $\mathrm{CO}_{2}$ ナルコーシスとなり， 呼吸不全に陷る。李た，リンパ液喪失によるリンパ球 の減少, $\gamma$-グロブリンの減少により, 液性抢よび細胞 性免疫能が低下する ${ }^{10}$ (図 5 )。症例 1 では, 感染症か ら DICを引き起こしたが, リンパ液喪失による免疫力 低下が感染の原因の 1 つであったと思われる。

胸管の走行には variationが多いといわれている が, 定型的走行は, 第 1 腰椎の前にある乳糜槽上り始 まり，横隔膜の大動脈裂孔を通り，大動脈と奇静脈の 間を上行，気管分岐部あたりから左方に交差し大動脈 弓から左総頸動脈の後方を上行して静脈角に流入す る9).それ仲光左鎖骨上リンパ節や左深頸リンパ節を 郭清する場合, 内頸静脈を露出し, 静脈角までリンパ 節郭清を行らので，この時胸管が損傷される可能性が ある。このため, 頸部操作中に胸管を損傷してもいい ように, あらかじめ胸腔内操作中に, 胸部下部で胸管 を結禁切開して打くことが重要である。第 2 症例以来, 当教室では, 食道癌で頸部リンパ節郭清を行ら症例は 全例, 胸管を結禁切断し, その上部は切除している.

診断は，頸部からの漏出液を乳糜であるかどらか診 断すればよい, 乳糜の一般的性状は, 乳白濁色, 無臭 でアルカリ性, ェーテル可溶性で, 検鏡にて脂肪球を 認め, Sudan 染色陽性であるので(46)89911112), これらの 所見を証明すればよい。しかし，通常は漏出液の外観 々臨床経過より容易に診断できる。

治療は，まず保存的療法を行い改善しなければ，外 科的療法を考慮する。保存的療法は，リンパ漏出部の 徹底した压迫と、リンパ液喪失に伴って失われるタン
パク質, 脂質, 水分, 電解質などの補給である。これ らの成分の補給には IVH が有効である。な和長鎖脂 肪酸摂取により胸管内のリンパ流量は $2 \sim 10$ 倍に増加 するといわれている9 . 一方, 中鎖脂肪酸は，胸管を通 ることなく直接閒脈系に吸収される゙9ので, 経口摂取, あるいは経腸栄養が可能なら，脂肪の補給には medium chain triglyceride (MCT) 療法が有効であ る。すなわち, 徹底した長鎖脂肪酸の制限により, 胸 管内を通る乳糜を最小限にしたらえで, 徹底したりン パ漏出部の圧迫を行うことが保存的療法では重要とな る. 症例 1 では, 経口や経腸栄養を行っている時は漏 出液量が増加し, IVH のみの時は減少した。これは, 経口や経腸栄養内に脂肪が含まれていたことにより， 胸管からの漏出液が増加したためと考兄られる。私達 の考壳では，保存的療法を $1 \sim 2$ 週間行っても，末だ 漏出液が認められる場合, なるべく早期に, 積極的に 外科的療法を行うべさであると考えている．胸管瘦閉 鎖術は局所麻酔下に行うことができ，手術侵襲も少な い. 症例 1 は, 保存的療法のみで予後不良であったが, 症例 2 では胸管瘦閉鎖術を行い良好な結果が得られ た.

最近は食道癌に対し，盛んに頸部リンパ節郭清が行 われている、したがって，今後，この上うな合併症が 増加することが予想され，十分な注意が必要である。

\section{結語}

食道癌頸部リンパ節郭清後に発症した頸部胸管瘻を 2 例経験した。 1 例に胸管㾇閉鎖術を施行し良好な結 果が得られた。

\section{文献}

1）掛川暉夫, 山名秀明, 藤田博正：胸部食道癌根治術 に打ける頝部リンパ節郭清の意義。外科診療 $28: 523-528,1986$

2）鶴丸昌彦, 秋山洋, 小野田由雅活か：胸部食道癌 のリンパ節郭清一特に頝部上縦リンバ節郭清につ

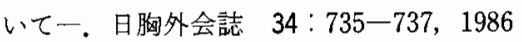

3）渡辺正敏,鈴木俊輔, 大津友見注か：持続陽王呼吸 と中心静脈栄養の併用に上る食道癌術後乳糜胸の 1 治験例。日胸外会誌 $30 ： 1330-1335,1982$

4）渡辺明彦, 中谷勝紀, 宮城信行汪か：食道癌切除後 飞発生した乳糜胸の1治験例. 臨外 41 : 509-512, 1986

5）信友政明, 北川陽一郎, 平中俊行ほか：食道癌食道 全摘後乳糜胸の 1 治験例. 日胸外会誌 $26: 1290$, 1978

6）吉村博邦，阿曾弘一：乳糜胸一この症例の治療方 針一. 外科 $48: 548-554,1986$ 
7）食道疾患研究会編：臨床・病理食道癌取扱い規約. 第 6 版，金原出版，東京， 1984

8）小會伸一, 佐藤 功, 平野正満ほか：外傷性胸管損 傷の 1 手術治験例について. 呼吸 $4: 594-598$, 1985

9）信田重光, 倉山英生：胸管リンパ喪失一病態生理 を中心に一。外科 48 : 578 - 582,1986
10）土田昌一, 中込正明, 広野達彦ほか：肺癌術後に併 発した乳糜胸の 3 治験例。日胸臨 $45: 780-784$, 1986

11）笹井巧, 土屋了介, 宮沢直人ほか：肺癌手術後の 乳糜胸の治療。日胸外会誌 $36: 1044-1048,1988$

12）池田道昭, 宇野 顕, 萩原 昇ほか：外傷性乳糜胸 の 1 手術治験例。胸部外科 $37: 543-546,1984$ 